\title{
The Ecological Role of Water-Column Microbes in the Sea*
}

\author{
F. Azam ${ }^{1}$, T. Fenchel ${ }^{2}$, J. G. Field ${ }^{3}$, J. S. Gray ${ }^{4}$, L. A. Meyer-Reil ${ }^{5}$ and F. Thingstad ${ }^{6}$ \\ ${ }^{1}$ Institute of Marine Resources, Scripps Institution of Oceanography, La Jolla, California 92093, USA \\ ${ }^{2}$ Institute of Ecology and Genetics, University of Aarhus, DK-8000 Aarhus-C, Denmark \\ ${ }^{3}$ Zoology Department, University of Cape Town, Rondebosch 7700, South Africa \\ ${ }^{4}$ Institutt for Marinbiologi og Limnologi, Universitetet i Oslo, Postboks 1064, Blindern, Oslo 3, Norway \\ ${ }^{5}$ Institut für Meereskunde, Universität Kiel, Düsternbrooker Weg 20, D-2300 Kiel 1, Federal Republic of Germany \\ ${ }^{6}$ Institute for Microbiology, University of Bergen, Bergen, Norway
}

\begin{abstract}
Recently developed techniques for estimating bacterial biomass and productivity indicate that bacterial biomass in the sea is related to phytoplankton concentration and that bacteria utilise 10 to $50 \%$ of carbon fixed by photosynthesis. Evidence is presented to suggest that numbers of free bacteria are controlled by nanoplanktonic heterotrophic flagellates which are ubiquitous in the marine water column. The flagellates in turn are preyed upon by microzooplankton. Heterotrophic flagellates and microzooplankton cover the same size range as the phytoplankton, thus providing the means for returning some energy from the 'microbial loop' to the conventional planktonic food chain.
\end{abstract}

\section{INTRODUCTION}

Bacteria and other micro-organisms have long been known to play a part in marine ecosystems (Sorokin, 1981), but it has been difficult to study them quantitatively. Traditional methods of enumerating marine bacteria were based on plate counts, serial dilutions or phase-contrast microscopy which gave estimates of, at best, $10 \%$ of actual numbers and have generally been discarded for estimating bacterial biomass. Recently several chemical techniques have been used to estimate biomass, these include ATP, (see review by Karl and Holm-Hansen, 1980; see also Sorokin and Lyutsarev, 1978), muramic acid (Fazio et al., 1977; Moriarty, 1977) and lipo-polysaccharides (LPS) (Watson et al., 1977). However, for estimating the biomass of natural assemblages in different physiological states these suffer from the drawback of having varying conversion factors between the cell component measured and bacterial biomass. The technique of epifluorescence microscopy has recently come into use for directly counting bacteria. The fluorescent dyes used

\footnotetext{
- All authors are members of the working group on bacteria and bacterivory, NATO Advanced Research Institute, Bombannes, France, May, 1982
}

include Acridine Orange (Francisco et al., 1973, Hobbie et al., 1977), DAPI (Porter and Feig, 1980) and Hoechst 33825 (Paul, 1982). The above combined with scanning or transmission electron microscopy for estimating bacterial volumes, give the best present estimates of bacterial biomass (Krambeck et al., 1981).

There have also been recent developments in estimating bacterial production rates. The most promising of these are the frequency of dividing cells (FDC) (Hagström et al., 1979) though it is tedious and difficult to calibrate satisfactorily, and Tritiated Thymidine Incorporation (TTI) (Fuhrman and Azam, 1980, 1982); it yields maximum estimates because of the conservative assumptions involved. To relate production to the active fraction of bacterial assemblages, TTI autoradiography may be used in combination with epifluorescence microscopy (Fuhrman and Azam, 1982).

Thus it is now possible to obtain realistic estimates of the biomass and productivity of bacteria in the sea, and to re-examine their role critically. This paper is confined to data based on acridine orange direct counts and electron microcopic estimates of biomass; it considers the new data on bacterial production.

Traditionally, bacteria have been regarded as remineralisers, responsible for converting organic mat- 
ter to inorganic and recycling nutrients to primary producers. We have considered the questions: Is this true? If so, how does it occur?

This short paper covers only the role of free bacteria in the water column; similar principles probably apply to bacteria on detrital particles and in sediments.

\section{BACTERIAL BIOMASS AND PRODUCTION}

Table 1 shows some recent estimates of bacterial numbers and biomasses in different marine environments obtained using epifluorescence microscopy for numbers combined with electron microscopy for biomass estimates. There is a general trend for increasing bacterial numbers and biomass with increasing primary productivity, a correlation confirmed by measurements in a range of natural and experimental situations (E. A. S. Linley and R. C. Newell, unpubl. •). The estimates for a given environment vary within $10^{4}$ to

Table 1. Biomass estimates of marine bacteria, summarized from Meyer-Reil (1982) and Es and Meyer-Reil (1982), assuming a conversion factor of $10 \%$ from live mass to carbon equivalent

\begin{tabular}{|lcc|}
\hline Environment & $\begin{array}{c}\text { Numbers } \\
\left(\times 10^{8} \mathrm{l}^{-1}\right)\end{array}$ & $\begin{array}{c}\text { Biomass } \\
\left(\mu \mathrm{g} \mathrm{C}^{-1}\right)\end{array}$ \\
\hline Estuaries & 50 & $?$ \\
Coastal waters & $10-50$ & $5-200$ \\
Offshore waters & $0.5-10$ & $1-5$ \\
Deep waters & 0.1 & $?$ \\
\hline
\end{tabular}

$5 \times 10^{6}$ cells $\mathrm{ml}^{-1}$, a relatively small range, suggesting that some homeostatic mechanism may operate. Of the bacterial biomass, up to 10 to $20 \%$ may be attached to particles, the majority are free bacterioplankton (Hobbie et al., 1972; Azam and Hodson, 1977). Even under unusual coastal conditions, such as in estuaries or kelp beds when much mucilage is released, only 11 to $14 \%$ of the bacterial biomass is attached to aggregates (Linley and Field, 1982).

There are only a few reliable estimates of bacterioplankton production rates because the methods have been developed so recently. These suggest that production may be 2 to $250 \mu \mathrm{g} \mathrm{C}^{-1} \mathrm{~d}^{-1}$ in coastal waters, with bacterioplankton production being 5 to $30 \%$ of primary production for both coastal and offshore waters (Es and Meyer-Reil, 1982). Fuhrman and Azam (1982) estimated that bacteria consume 10 to $50 \%$ of total fixed carbon, assuming a carbon conversion efficiency of $50 \%$. However, a wide range of carbon con-

\footnotetext{
- Institute for Marine Environmental Research, Plymouth England
}

version efficiencies have been reported. Pure culture experiments reviewed by Calow in Townsend and Calow (1981) - see also Koch (1971), Payne and Wiebe (1978) and Williams (1981) - give values in the range 40 to $80 \%$ of carbon substrate being converted to bacterial carbon. Newell and co-workers (Linley and Newell, 1981; Newell et al., 1981; Stuart et al., 1982) obtained values in the range 6 to $33 \%$ in microcosm experiments using natural seawater on a variety of types of plant debris. High carbon conversion efficiencies appear to occur under nutrient-rich (especially nitrogen-rich) conditions (Newell, pers. comm.). If this proves to be true, it suggests that bacteria consume carbon as a source of energy while scavenging nitrogen for protein synthesis. The results of Koop et al. (1982) in an in situ microcosm experiment support this concept, since they found carbon in kelp debris was incorporated in bacteria at $28 \%$ efficiency, whilst nitrogen was incorporated at $94 \%$ efficiency. The rate of respiration of bacteria appears to be linearly related to their growth rate (Fenchel and Blackburn, 1979), the exact relationship depending upon the carbon conversion efficiency. The proportion of carbon respired is (1proportion of carbon assimilated), thus present estimates range from 40 to $90 \%$ of absorbed carbon being respired by bacteria. This calculation assumes that a negligible amount of carbon is excreted by bacteria, an assumption that is probably generally valid although there is some qualitative evidence suggesting that molecules of small size may be excreted (Itturriaga and Zsolnay, 1981; Novitsky and Kepkay, 1981).

\section{CONDITIONS FAVOURING BACTERIAL GROWTH}

Fuhrman et al. (1980) have shown that off California there is a good correlation between the distribution of chlorophyll and bacteria on a scale of tens of kilometres. Bacteria also show seasonal patterns of abundance, presumably in response to dissolved organic matter (DOM) released by phytoplankton (Meyer-Reil, 1977; Larsson and Hagström 1979). It appears that DOM is released by some species of phytoplankton as nutrients are depleted at the end of a bloom. The fraction of labile photosynthate released is probably in inverse proportion to the concentration of the limiting nutrient, as shown for nitrogen in Fig. 1 (Joiris et al., 1982; Sakshaug, pers. comm.). DOM release (in the form of glucan) is also evident on a diel scale, glucan being synthesized and excess released during daylight and being utilised for protein synthesis that continues through the dark hours (Barlow, 1982; Sakshaug, pers. comm.). These cycles of DOM release obviously have implications for bacterial 
growth. Further evidence of inter-related diel rhythms is that the specific growth rate of heterotrophic water column bacteria increases significantly during daylight and decreases at night (Sieburth et al., 1977; Azam, 1982; Fuhrman et al., unpubl.). This is supported by free amino-acid and DOC measurements showing a similar diel pattern in the water column (Meyer-Reil et al., 1979).

Natural selection appears to favour motility amongst water column bacteria (Koop, 1982), as opposed to those in marine sediments, although there is little quantitative information on this. There is evidence that bacteria show kinesis in a field 10 to $100 \mu \mathrm{m}$ from algal cells, close enough to take advantage of DOM (Azam, in press). Under laboratory conditions in natural seawater, bacteria were observed to remain at distances of the order of $10 \mu \mathrm{m}$ from algal cells, possibly being repelled by antibiotics produced by healthy algae. They attach mainly to moribund algae.

\section{FACTORS LIMITING BACTERIA IN THE SEA}

Since the respiration of aerobic marine bacteria is linearly related to their growth rate (Fenchel and Blackburn, 1979), and the slope of the line appears to depend on other nutrients, principally nitrogen for protein synthesis (see p. 261), it follows that the supply of either carbon for energy, or other nutrients may limit bacterial growth. However, in phytoplankton blooms DOM is often produced, and bacteria with their large surface: volume ratio are adapted to scavenging nutrients from the water at very low concentrations. The difficulties experienced in quantifying the release of DOM by algae are almost certainly due to its rapid uptake by bacteria. The same argument applies to nutrient cycling. If bacteria are so well adapted to

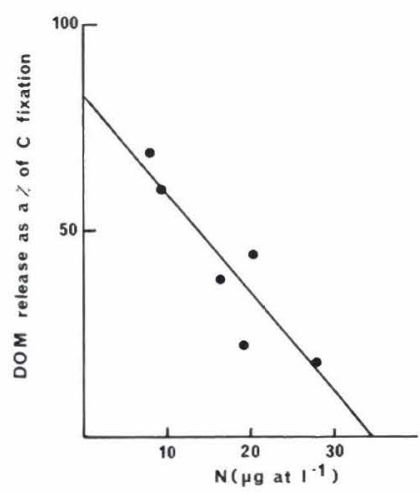

Fig. 1. Release of DOM by phytoplankton, expressed as percentage of carbon fixed in photosynthesis, and plotted against nitrogen concentration. (After Joiris et al., 1982). Similar relationships have been found for several phytoplankton species, with varying slopes scavenging DOM and nutrients at low concentrations, what limits their population size to the biomass levels given in Table 1? Fenchel (1982a, b, c, d, in press) has shown that heterotrophic microflagellates in the size range 3 to $10 \mu \mathrm{m}$ are effective bacteriovores in the sea, capable of filtering 12 to $67 \%$ of the water column per day (see also Sorokin, 1979; Sieburth, 1982). These are principally choanoflagellates and colourless chrysomonads which occur ubiquitously in seawater reaching densities of more than $10^{3}$ cells $\mathrm{ml}^{-1}$ (Sieburth, 1979; Fenchel, 1982a-d). Field observations have shown predator/prey oscillations between bacteria and

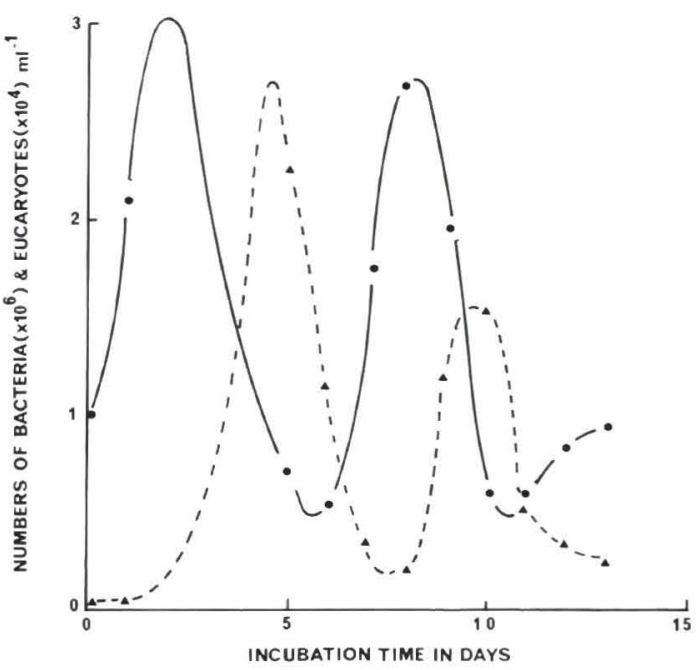

Fig. 2. Oscillations in the density of bacteria and small ( 3 to 10 $\mu \mathrm{m})$ eucaryotic organisms after addition of crude oil to a $10 \mathrm{l}$ sample of natural seawater. Population of eucaryotic organisms was totally dominated by small flagellates. Incubation at $15^{\circ} \mathrm{C}$ in darkness. (Thingstad unpubl.)

the total flagellate fauna with a lag of $4 \mathrm{~d}$ between bacterial and flagellate peaks (Fenchel, 1982d). In the laboratory pure cultures of flagellates show balanced growth with generation times of about $24 \mathrm{~h}$ at bacterial concentrations of around $10^{6}$ cells $\mathrm{ml}^{-1}$ (Fenchel, 1982b).

Fig. 2 shows the predator/prey oscillations in laboratory experiments where bacterial growth in natural seawater has been stimulated by the addition of crude oil (Thingstad et al., unpubl.). In this instance oil provided an artificial and increased carbon source as nutrition for the bacteria, but in natural systems the carbon is normally produced by the release of DOM from living or moribund cells. This and mesocosm experiments conducted in $20 \mathrm{~m}$ high columns, $1 \mathrm{~m}$ in diameter, in the Lindåspolls in Norway show that as the phytoplankton bloom declined, bacterial populations built up and these in turn declined when flagellates became abundant (Thingstad, unpubl.) Newell (in press) summarizes the results of microcosm experi- 
ments on the degradation of DOM, kelp debris, animal faeces, phytoplankton and Spartina debris which all show the same successional pattern in natural seawater. Thus all the evidence to date suggests a remarkably similar pattern, with heterotrophic microflagellates controlling bacterial numbers with a lag of some 3 to $4 \mathrm{~d}$ between bacterial and flagellate peaks.

Physical and physiological constraints favour small organisms as bacteriovores because of their large surface-to-volume ratio which increases the probability of contact with bacteria (Fenchel, in press). A notable exception to this is provided by Oikopleura which have giant filters with mesh sizes of bacterial dimensions (Flood, 1978; King et al., 1980), analogous to baleen whales (Fenchel, in press). Free-living bacteria in the water column can be utilised to some extent by some larger animals such as sponges (Reiswig, 1974, 1975), and bivalves (Jørgensen, 1966; Stuart et al., 1982; Wright et al., 1982). However, bacteria are at the lower limit of efficient utilisation on an extensive scale by macrofauna - many orders of magnitude larger than the bacteria themselves. Thus while bacteria may provide nutritive supplements of some of these animals, it is doubtful whether macrofauna play a significant role in controlling bacterial populations on a large scale.

\section{HYPOTHESIS OF THE "MICROBIAL LOOP"}

Water column bacteria utilise DOM as an energy source, and this is mainly of phytoplankton origin since it has been estimated that 5 to $50 \%$ of carbon fixed is released as DOM (see review by Larsson and Hagström, 1982). There is also a close correlation between bacterial and primary production (Es and Meyer-Reil, 1982).

Fig. 3 presents a modification of the Sheldon (1972) particle-size model to illustrate the role of bacteria and other microbes in the water column. The main feature of Sheldon's model is that organisms tend to utilise particles one order of magnitude smaller than themselves. DOM released by phytoplankton and, to a much smaller extent by animals, is utilised by bacteria. When sufficient DOM is supplied for their growth, bacteria $(0.3$ to $1 \mu \mathrm{m})$ are kept below a density of 5 to $10 \times 10^{6}$ cells $\mathrm{ml}^{-1}$, primarily by heterotrophic flagel-

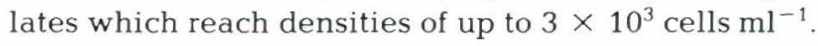
Flagellates ( 3 to $10 \mu \mathrm{m}$ ) probably also feed on autotrophic cyanobacteria in the same size range $(0.3$ to 1 $\mu \mathrm{m})$. Cyanobacteria have rarely been counted separately but are included in most direct counts of bacteria. Flagellates eat them because they are in the particle sizes ingested. Flagellates, both autotrophic and heterotrophic, are in turn preyed upon by microzooplankton in the same size range as the larger

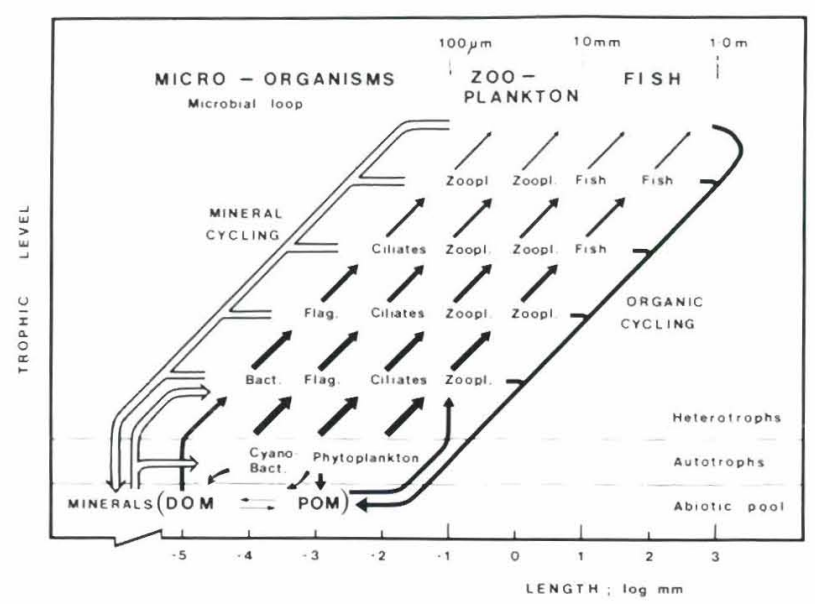

Fig. 3. Semi-quantitative model of planktonic food chains. Solid arrows represent flow of energy and materials; open arrows, flow of materials alone. It is assumed that $25 \%$ of the net primary production is channelled through DOM and the "microbial loop", bacteria (Bact.), filageliates (Flag.) and other micro-zooplankton (e.g. ciliates). It is further assumed that the most efficient predator prey size ratio is $10: 1$, hence the slope of the lines relating trophic status to $\log$ body length is $1: 1$. The food chain base represents a size range 3 orders of magnitude (smallest bacteria $0.2 \mu \mathrm{m}$, largest diatoms $200 \mu \mathrm{m}$; therefore, any trophic level will have a size-range factor of $10^{3}$ and conversely each size class of organisms $(100 \mu \mathrm{m})$ will represent at least 3 trophic levels. The thickness of open arrows (left) represents the approximate relative magnitude of minerals released in excretion at each trophic level; corresponding organic losses (faeces, mucus, etc.) are shown on the right hand side

phytoplankton (10 to $80 \mu \mathrm{m}$ ). Thus energy released as DOM by phytoplankton is rather inefficiently returned to the main food chain via a microbial loop of bacteriaflagellates-microzooplankton.

\section{DISCUSSION}

An important consequence of the "microbial loop" described above, stems from the ability of bacteria to absorb mineral nutrients from the sea. Their small size and large surface-to-volume ratio allow absorption of nutrients at very low concentrations, giving them a competitive advantage over phytoplankton as documented in CEPEX bag and laboratory experiments (Vaccaro et al., 1977; Albright et al., 1980). Flagellates, by their strong predatory control of bacterial density, may play an important role in influencing the result of competition for nutrients between phytoplankton and bacteria (Thingstad, unpubl.). Bacteria sequester mineral nutrients efficiently and are consumed by flagellates with a carbon assimilation efficiency of some $60 \%$ (Fenchel, 1982b), the remaining $40 \%$ of carbon being egested as faeces. Furthermore, heterotrophic flagellates and other microzooplankton, excrete nitro- 
gen and since their $\mathrm{C} / \mathrm{N}$ ratios are similar to that of their food (3.5 to 4) (Fenchel and Blackburn, 1979) an amount of nitrogen corresponding to some $25 \%$ respired carbon must also be excreted. While bacteria also excrete minerals and respire carbon, they compete efficiently to regain mineral nutrients; it therefore remains for the heterotrophic flagellates and microzooplankton to play the major role in remineralization in the sea. This is contrary to the classical view of bacteria as remineralizers, but is a view shared by Mann (1982).

The role of the 'microbial loop', including microzooplankton, is likely to be particularly important in rapidly recycling nutrients above the thermocline. This is because bacteria attached to particles and larger phytoplankton cells are likely to sink out of the mixed layer faster than the free-living (motile) bacteria (Wangersky, 1977; Kirchman et al., 1982). Evidence is provided by Fuhrman and Azam (unpubl.) who found that free and attached bacteria above the thermocline were adapted to warm temperatures by showing optimal activity at $17^{\circ} \mathrm{C}$. However, bacteria obtained from $200 \mathrm{~m}$ depth varied in their thermal optima, free bacteria showing optimal activity at ambient temperature implying long residence at depth while bacteria attached to particles showed optimal activity at higher temperature, suggesting recent origin from above the thermocline.

The dynamic behaviour of the 'microbial loop' is a result of several interacting ecological relationships: commensalism, competition and predation. Commensalism occurs in the production of DOM by phytoplankton and utilization by bacteria. DOM production is influenced by the availability of mineral nutrients (Fig. 1). Competition for mineral nutrients is found between phytoplankton and bacteria. This is influenced by the growth conditions for algae as well as the availability of organic substrates for bacterial growth. Predation by microflagellates on bacteria influences the outcome of the competition mentioned above. The regeneration of mineral nutrients resulting from predation will provide a feedback of some of the material flows within the "microbial loop".

From this it should be evident that carbon and mineral nutrient flows in the 'microbial loop' are tightly coupled. Information on the nature of this coupling is thus essential for an understanding of the dynamical behaviour of the 'microbial loop'. Since many marine pollution situations include the addition of mineral nutrients and/or organic carbon to the ecosystem, an understanding of the regulating mechanisms within the "microbial loop" is important.

Acknowledgements. We thank P. J. le B. Williams, C. Joiris, E. Sakshaug and R. C. Newell for stimulating discussions during the NATO Advanced Research Institute held at Bom- bannes, France, in May 1982. We thank Dr. M. I. Lucas, IMER, Plymouth, who generously helped design and draw Fig. 3.

\section{LITERATURE CITED}

Albright, L. J., Chocair, J., Masuda, K., Valdes, D. M. (1980). In situ degradation of the kelp Macrocystis integrifolia and Nereocystis laetkeana in British Columbia waters. Nat. Can. 107: 3-10

Azam, F. (1982). Measurement of growth of bacteria in the sea and the regulation of growth by environmental conditions. In: Hobbie, J., Williams, P. J. Le B. (eds.) Heterotrophic activity in the sea. Plenum Press, in press

Azam, F., Hodson, R. E. (1977). Size distribution and activity of marine microheterotrophs. Limnol. Oceanogr. 22: 492-501

Barlow, R. G. (1982). Phytoplankton ecology in the Southern Benguelan Current: 2. Carbon assimilation patterns. J. exp. mar. Biol. Ecol. 63: in press

Es, F. B. van, Meyer-Reil, L. A. (1982). Biomass and metabolic activity of heterotrophic bacteria. Adv. microb. Ecol., in press

Fazio, S. D., Mayberry, W. R., White, D. C. (1978). Muramic acid assay in sediments. Mar. Biol. 48: 185-197

Fenchel, T. (1982a). Ecology of heterotrophic microflagellates. 1. Some important forms and their functional morphology. Mar. Ecol. Prog. Ser. 8: 225-231

Fenchel, T. (1982b). Ecology of heterotrophic microflagellates. II. Bioenergetics and growth. Mar. Ecol. Prog. Ser. 8: 225-231

Fenchel, T. (1982c). Ecology of heterotrophic microflagellates. III. Adaptations to heterogeneous environments. Mar. Ecol. Prog. Ser. 9: 25-33

Fenchel, T. (1982d). Ecology of heterotrophic microflagellates. IV. Quantitative occurrence and importance as consumers of bacteria. Mar. Ecol. Prog. Ser. 9: 35-42

Fenchel, T. (1983). Suspended marine bacteria as food source In: Fasham, M. J. (ed.) NATO Advanced Research Institute: Flow of energy and materials in marine ecosystems. Plenum Press, in press

Fenchel, T., Blackburn, T. H. (1979). Bacteria and mineral cycling, Academic Press, London

Flood, P. R. (1978). Filter characteristics of appendicularian food catching nets. Experientia 34: 173

Francisco, D. E., Mah, R. A., Rabin, A. C. (1973). Acridine orange epifluorescence technique for counting bacteria. Trans. Am. Micros. Soc. 92: 416-421

Fuhrman, J. A. (1981). Influence of method on the apparent size distribution of bacterioplankton cells: epifluorescence microscopy compared to scanning electron microscopy. Mar. Ecol. Prog. Ser. 5: 103-106

Fuhrman, J. A., Ammerman, J. W., Azam, F. (1980). Bacterioplankton in the coastal euphotic zone: distribution, activity and possible relationships with phytoplankton. Mar. Biol. 60: 201-207

Fuhrman, J. A., Azam, F. (1980). Bacterioplankton secondary production estimates for coastal waters of British Columbia, Antarctica and California. Appl. environ. Microbiol. 39: $1085-1095$

Fuhrman, J. A., Azam, F. (1982). Thymidine incorporation as a measure of heterotrophic bacterioplankton production in marine surface waters: evaluation and field results. Mar. Biol. 66: 109-120

Hagström, A., Larsson, U., Hörstedt, P., Normark, S. (1979). Frequency of dividing cells, a new approach to the deter- 
mination of bacterial growth rates in equatic environments. Appl. environ. Microbiol. 37: 805-812

Hobbie, J. E., Daley, R. J., Jasper, S. (1977). Use of Nucleopore filters for counting bacteria by fluorescence microscopy. Appl. environ. Microbiol. 33: 1225-1228

Hobbie, J. E., Holm-Hansen, O., Packard, T. T., Pomeroy, L. R., Sheldon, R. W., Thomas, J. P., Wiebe, W. J. (1972). A study of the distribution and activity of microorganisms in ocean water. Limnol. Oceanogr. 17: 544-555

Itturiaga, R., Zsolnay (1981). Transformation of some dissolved organic components by a natural heterotrophic population. Mar. Biol. 62: 125-129

Jørgensen, C. B. (1966). Biology of suspension feeding, Pergamon Press, Oxford

Joiris, C., Billen, G., Lancelot, C., Daro, M. H., Mommaerts, J. P., Hecq, J. H., Bertels, A. Bossicarta, M., Nijs, J. (1982) A budget of carbon cycling in the Belgian coastal zone. Relative roles of zooplankton, bacterioplankton and benthos in the utilization of primary production. Neth. J. Sea. Res., in press

Karl, D. M., Holm-Hansen, O. (1975). Methodlogy and measurement of adenyldte energy charge ratios in environmental samples. Mar. Biol. 48: 185-197

King, K. R., Hollibaugh, J. T., Azam, F. (1980). Predator-prey interactions between the larvacean Oikopleura dioica and bacterioplankton in enclosed water columns. Mar. Biol. 56: 49-57

Kirchman, D., Mitchell, R. (1982). Contribution of particle bound bacteria to total microheterotrophic activity in five ponds and two marshes. Appl. environ. Microbiol. 43: 200-209

Koch, A. L. (1971). The adaptive response of Escherichia coli to a feast and famine existence. Adv. Microb. Physiol. 6: $147-217$

Koop, K. (1982). Fluxes of material associated with the decomposition of kelp on exposed sandy beaches and adjacent habitats. Ph. D. thesis, University of Cape Town

Koop, K., Newell, R. C., Lucas, M. I. (1982). Microbial regeneration of nutrients from the decomposition of macrophyte debris on the shore. Mar. Ecol. Prog. Ser. 9: 91-96

Krambeck, C., Krambeck, H.-J., Overbeck, J. (1981). Microcomputerassisted biomass determination of plankton bacteria on scanning electron micrographs. Appl. environ. Microbiol. 42: 142-149

Larsson, U., Hagström, §. (1979). Phytoplankton exudate release as an energy source for the growth of pelagic bacteria. Mar. Biol. 52: 199

Larsson, U., Hagström, §̊. (1982). Fractionated phytoplankton primary production, exudate release, and bacterial production in a Baltic eutrophication gradient. Mar. Biol. 67: $57-70$

Linley, E. A. S., Newell, R. C. (1981). Microheterotrophic communities associated with the degradation of kelp debris. Kieler Meeresforsch. 5: 345-355

Linley, E. A. S., Field, J. G. (1982). The nature and ecological significance of bacterial aggregation in a near-shore upwelling ecosystem. Estuar. coast. Shelf. Sci.

Mann, K. H. (1982). The ecology of coastal waters: a systems approach, Blackwell, Oxford

Meyer-Reil, L.-A. (1979). Bacterial growth rates and biomass production. In : Rheinheimer, G. (ed.) Microbial ecology of a brackish water environment. Springer-Verlag, Berlin, pp. 223-236

Meyer-Reil, L.-A. (1982). Bacterial biomass and heterotrophic activity in sediments and overlying waters. In: Hobbie, J. Leb, E., Williams, P. J. (eds.) Heterotrophic activity in the sea. Plenum Press, New York, in press
Meyer-Reil, L.-A., Bolter, M., Liebezeit, G., Schramm, W., (1979). Short-term variations in microbiological and chemical parameters. Mar. Ecol. Prog. Ser. 1: 1-6

Meyer-Reil, L.-A., Dawson, R., Liebezeit, G., Tiedge, H. (1978). Fluctuations and interactions of bacterial activity in sandy beach sediments and overlying waters, Mar. Biol. 48: $161-171$

Moriarty, D. J. W. (1977). Improved method using muramic acid to estimates biomass of bacteria in sediments. Oecologia 26: 317-323

Newell, R. C. (1983). The biological role of detritus in the marine environment. NATO Advanced Research Institute. In: Fasham, M. J. (ed.) Flow of energy and materials in marine ecosystems. Plenum Press, New York, in press

Newell, R. C., Lucas, M. I., Linley, E. A. S. (1981). Rate of degradation and efficiency of conversion of phytoplankton debris by marine microorganims. Mar. Ecol. Prog. Ser. 6: 123-136

Novitsky, J. A., Kapkay, P. E. (1981). Patterns of microbial heterotrophy through changing environments in a marine sediment. Mar. Ecol. Prog. Ser. 4: 1-7

Paul, J. H. (1982). Use of Hoechst dyes 33258 and 33342 for enumeration of attached and planktonic bacteria. Appl. environ. Microbiol. 43: 939-944

Payne, W. T., Wiebe, W. J. (1978). Growth yield and efficiency in chemosynthetic microorganisms. Ann. Rev. Microbiol 32: $115-183$

Porter, K. G., Feig, Y. S. (1981). The use of DAPI for identifying and counting aquatic microflora. Limnol. Oceanogr 25: 943-948

Reiswig, H. M. (1974). Water transport, respiration and energetics of three tropical marine sponges. J. exp. mar. Biol. 14: 231-249

Reiswig, H. M. (1975). The aquiferous systems of three marine demospongiae. J. Morphol. 145: 493-502

Sheldon, R. W., Prakash, A., Sutcliffe, W. H. (1972). The size distribution of particles in the ocean. Limnol. Oceanogr. 17: $327-340$

Sieburth, J. Mc. N. (1979). Sea microbes, Oxford University Press, New York

Sieburth, J. McN. (1982). Grazing of bacteria by protozooplankton in pelagic marine waters. In: Hobbie, J. E., Williams, A. J. Le B. (eds.) Heterotrophic activity in the sea. Plenum Press, New York, in press

Sieburth, J. McN., Johnson, K. M., Burney, C. H., Lavoie, D. M. (1977). Estimation of in situ rates of heterotrophy using diurnal changes in dissolved organic matter and growth rates of picoplankton in diffusion culture. Helgoländer wiss. Meeresunters. 30: 565-570

Sorokin, Y. I. (1979). Zooflagellates as a component of eutrophic and oligotrophic communities of the Pacific Ocean. Okeanologiya 3: 476-480

Sorokin, Y. I. (1981). Microheterotrophic organisms in marine ecosystems. In: Longhurst, A. R. (ed.) Analysis of marine ecosystems. Academic Press, London, pp. 293-342

Sorokin, Y. I., Lyursarev, S. V. (1978). A comparative evaluation of two methods for determining the biomass of planktonic microflagellates. Oceanol. Acad. Sci. U.S.S.R. 18: 232-236

Stuart, V., Field, J. G., Newell, R. C. (1982). Evidence for absorption of kelp detritus by the ribbed mussel Aulacomya ater using a new ${ }^{51} \mathrm{Cr}$-labelled microsphere technique. Mar. Ecol. Prog. Ser. 9: 263-271

Townsend, C. R., Calow, P. (eds.) (1981). Physiological ecology: an evolutionary approach to resource use, Blackwell, Oxford

Vaccaro, R. F., Azam, F., Hodson, R. E. (1977). Response of 
natural marine bacterial populations to copper: controlled ecosystem pollution experiment. Bull. mar. Sci. 27: 17-22

Wangersky, P. J. (1977). The role of particulate matter in the productivity of surface waters. Helgoländer wiss. Meeresunters. 30: 546-564

Watson, S. W., Novitsky, J. A., Quinby, H. L., Valois, F. W. (1977). Determination of bacterial number and biomass in the marine environment. Appl. environ. Microbiol. 33: 940:947

Wiebe, W. J., Pomeroy, L. R. (1972). Microorganisms and their association with aggregates and detritus in the sea: a microscopic study. In: Melchiom-Santolini, U., Hopton, J. W. (eds.) Detritus and its role in aquatic ecosystems. Mem. Ist. Ital. Idrobiol. 24 (Suppl.): 325-352

Williams, P. J. Le B. (1981). Incorporation of microheterotrophic processes into the classical paradigm of the planktonic food web. Kieler Meeresforsch. Sondh. 5: 1-28

Wright, R. T., Coffin, R. B., Ersing, C. P., Pearson, D. (1982). Field and laboratory measurements of bivalve filtration of natural marine bacterioplankton. Limnol. Oceanogr. 27 : 91-98

This paper was submitted to the editor; it was accepted for printing on October 5, 1982 


\section{Erratum}

Re: Azam et al., Mar. Ecol. Prog. Ser. 10: 257-263, 1983

- On p. 257, right column, 13th line should read 'yields minimum estimates' 